\title{
ANOMIE IN AMERICAN BUSINESS SYSTEM AS AN AFTERMATH OF THE AMERICAN DREAM: DAVID MAMET”S “AMERICAN BUFFALO” AND "GLENGARRY GLEN ROSS"
}

\author{
AMERIKAN DÜŞÜ'NÜN KÖTÜ BİR SONUCU OLARAK AMERIKKAN İŞ \\ SISTEMINDE ANOMI: DAVID MAMET'İN “AMERICAN BUFFALO” VE \\ “GLENGARRY GLEN ROSS” ADLI OYUNLARI
}

\section{F. Gül KOÇSOY* - Eda GÜZELÇİÇEK ${ }^{* *}$}

\begin{abstract}
In this article, the concept of 'anomie' in David Mamet's (1947-) “American Buffalo" (1976) and "Glengarry Glen Ross" (1984) is analysed in the context of the economic and socio-cultural evolution of America and 'The American Dream of Success'. It is shown how virtues and values with the mentality of the system and with the name of 'business' transform into exploitable commodifications in the plays, which are designed as the microcosms of American capitalist business system. The anomic characters who behave under the pressures of the material success based American dream and with the malpractices of the American business system transgress the ethic conceptions and norms in the course of their struggle of survival; they keep pace with this order, legalize and normalize it. Moreover, they commit crimes for the sake of material gain and in the name of business, individually and collectively. The unbalance between the characters' right and ordinary aim of existence/being successful and the unethical means they employ to reach it forms the state of anomie and gives way to their inclination to behavioral deviation and violence. In the study, the negative results of the lack of ethics on individuals and society are presented referring to the anomie theories of Emile Durkheim, Robert Merton, Steven F. Messner and Richard Rosenfeld. The disruptive influences of American business system's norms, which disregard ethics and the individual and social conflicts they generate are exhibited.
\end{abstract}

Keywords: Anomie, American dream, David Mamet, "American Buffalo" "Glengarry Glen Ross".

ÖZ: Bu makalede, Amerika'nın ekonomik ve sosyo-kültürel dönüşümleri ve 'Amerikan Başarı Düșü' bağlamında David Mamet'in (1947-) "American Buffalo" (1976) ve "Glengarry Glen Ross" (1984) adlı oyunlarındaki 'anomi' kavramı açımlanmıştır. Amerikan kapitalist iş sisteminin birer mikrokozmu olarak tasarlanmış olan oyunlarda erdem ve değerlerin sistemin zihniyetiyle ve 'iş̧' adıyla nasıl sömürülebilir metalara dönüştükleri gösterilmiştir. Maddi başarı temelli Amerikan düşünün baskıları ve Amerikan iş sistemin yanlış uygulamalarıla hareket eden anomik karakterler hayatta kalma mücadelesi süreçlerinde etik kavramları ve normları çiğnerler; bu düzene ayak uydurup onu meşrulaștırarak normalleștirirler. Hatta maddi kazanç uğruna ve iş yapma adına bireysel veya kitlesel olarak suç işlerler. Karakterlerin var

* Doç. Dr. - Fırat Üniversitesi İnsani ve Sosyal Bilimleri Fakültesi Batı Dilleri ve Edebiyatları Bölümü / Elazı̆̆ - fgulkocsoy@firat.edu.tr (Orcid ID: 0000-0002-7813-8961)

** Uzman - Milli Eğitim Bakanlığı / İstanbul - edazirek@gmail.com (Orcid ID: 0000-00027274-5672)

This article was checked by Turnitin. 
olma/başarılı olma gibi haklı ve sıradan amaçları ile bunlara ulaşmada kullandıkları etik-dışı araçlar arasındaki dengesizlik anomi durumunu oluşturmakta, davranış sapmaları ve şiddete yönelmelerine yol açmaktadır. Çalışmada, Emile Durkheim, Robert Merton, Steven F. Messner ve Richard Rosenfeld'in anomi kuramlarına dayanılarak, etik yoksunluğunun birey ve toplum üzerindeki olumsuz sonuçları açıklanmıştır. Etik gözetmeyen Amerikan işs sistemi normlarının yıkıcı etkileri ve oluşturdukları bireysel ve toplumsal çeliş̧iler sergilenmiștir.

Anahtar Kelimeler: Anomi, Amerikan düşü, David Mamet, "American Buffalo", "Glengarry Glen Ross".

\section{Introduction}

At the outset of its foundation, with the help of Puritan work ethic, America -'the land of opportunity'- offers its inhabitants equal chance to achieve their own dreams of 'pursuit of happiness' through hard work, courage and determination. These dreams are the means for the perfection of the society through a set of social and moral ideals. However in the course of time, Puritan approach towards the dreams as the spiritual goal of receiving God's grace, transforms into gaining material success and the American Dream (of Success) which was originally theorized and encouraged to form a holistic common well-being, unfortunately evolves into a mere aim of pursuit of individual success and wealth. Later, with the secularization of Puritanism, economic and socio-political concerns became prevailing.

The term 'American Dream' was first employed by J.T. Adams in 1931. He puts forward that the contribution of America to the world is:

"The American dream, that dream of a land in which life should be better and richer and fuller for everyone, with opportunity for each according to ability or achievement. It is a difficult dream for the European upper classes to interpret adequately, and too many of us ourselves have grown weary and mistrustful of it. It is not a dream of motor cars and high wages merely, but a dream of social order in which each man and each woman shall be able to attain to the fullest stature of which they are innately capable, and be recognized by others for what they are, regardless of the fortuitous circumstances of birth or position" (2021).

In his description, Adams firstly points out the optimistic side of the dream by referring to its aspect of equal opportunity for everyone according to her/his ability. Secondly, he mentions the changing face of it; he makes clear distinctions between individual self-gain, which is symbolized with 'motor cars and high wages' and common good. Moreover, this romantic theory does not fit into practice. Seeing that the practice of the Dream does not correspond to the hopes and expectations claimed in its theory, he reveals mistrust towards it.

Centrality of financial success, imposed by the American Dream in comparison with other common virtues, preponderates and governs the concept of community and breaks individuals' bonds with their society, since 
the happiness is taught to be found only through monetary gains and individuality. Imperatives of the dream not only cause detachment from the ethical norms of socio-cultural environment, but also inject the illusion of 'otherness'. Reconciliation in society, then, turns out to be impossible since presence of the 'other' is considered as a threat, or if not, perceived as a soulless property available to exploit. Coexistence becomes completely impractical and individuals are coerced to find their own ways to secure their own existence and happiness. The exaggerated promises of the American Dream of success hypnotize the individuals and throw them into an illusionary world. Theoretical facet of the dream filled with optimism and promise of openness to everyone, is in contradiction with the practice in the restricted structure of the system. In this sense, it would not be wrong to consider American Dream as an oxymoron. In reality, 'America' is not able to meet the feasibility of the 'dream'; however, it is the exact place to run after it. Carlin humorously emphasizes the paradox of the dream; “...the reason they call it the American Dream is because you have to be asleep to believe it" (1997: 83).

The rhetoric of the dream explicates that every individual has an equal opportunity to succeed in America as long as he/she works hard and 'play by the rules', yet 'the rules' are not publicized and are replied subjectively. Subjective answers to the question are the premises of individualism and pragmatism, which focuses on practical and beneficial ends. Individualism supports that an individual is prior to any structure in society. Although originally theorized for the sake of common goodness, the idea of individualism embedded in the dream alters this communal point of view. William James (1842-1910), as the founder of American pragmatism and celebrator of American individualism, puts forward that the criteria of ethic calculations can only be assessed relative to the 'truth' of the individual. He states "...what is better for us to believe is true unless the belief incidently clashes with some other vital benefit" (2012:1276). Everything considered as 'better' and functional for the individual is blessed by the pragmatist idea. In the 'rugged' version of the American dream, as it is in pragmatism, material realities and their availability for the benefit of individual have priority over broader public benefits. Social Darwinism, in addition to individualism and pragmatism contributes to the dream's transformation into a material aim. It was developed by Herbert Spencer and is the application of Charles Darwin's theory of the evolutionary 'survival of the fittest' into laissez faire economy. According to it, 'unfavourable' enterprises, that were weak, are destined to extinct for the benefit of advancement. For the working class, ones who are unable to adapt themselves to the changing conditions of labor will be eliminated. The 'law(s) of competition' which are constantly reoriented and modified as befitting to the private interest of the individuals are merely the laws of jungle. This scientific but detached approach to humanity forms the very core of the American business ethic. American 
Dream, with the defense of individualism, pragmatism and Social Darwinism, found its theoretical basis for necessity of pursuit of property.

In this frame the necessity of 'rising from the masses' shows itself. Individuals' search of happiness somehow clashes with other individuals' search of happiness; then, 'success at the cost of someone else' becomes inevitable. David Mamet who considers economic life in America as a lottery comments about 'the American myth' (the dream) as such: "Instead of rising with the masses, one s hould rise from the masses. Your extremity is my opportunity. That is what forms the basis of our economic life, and this is what forms the rest of our lives. That American myth: the idea of something out of nothing....one feels one can only succeed at the cost of someone else" (1996: 178). Americans from the beginning of the 19 th century with the increase of industrialism became preoccupied with the anxieties of material property and status. Peasants immigrated to new industrial cities for the sake of actualizing their dreams since the dream promises that their fate was on their hands, but they had to sacrifice their foremost humane values because of class distinction and imagined that they would be prosperous, if they worked hard. After all, "...Americans' pursuit of success is substantially about material accumulation rather than the development of moral values" (Köseman, 2016: 175).

In the contemporary America, social and economic realities do not fit to those of the myth. The inevitable temptation of personal profit overbalances other communal anxieties and gives way to moral corruption. An individual who is alienated from social responsibility and social consciousness has modified the reality according to requirements of his illusion(s). He reconstructs the truth not according to the universal norms of living but to the business rules, which serve his personal aims in turn. The person left alone in the battlefield of American business system without any guidance, is forced to reconstruct and redefine norms in keeping with his illusion(s) and the person who is unable to establish conformity and orientation between reality and dream becomes frustrated. Both types of people are misled by the state of anomie, which was first used by Emile Durkheim (1858-1917) in The Division of Labor in Society (1893).

Anomie, as an aftermath of especially economic crises, refers to the absence or weakness of social norms, values and regulation. Anomie is defined as "...great difficulties of individual adaptation, resulting in a loss of general social orientation, the development of feelings of insecurity and marginalization, uncontrolled rising expectations, feelings of relative deprivation and the questioning of the legitimacy of core social values" (Orrú, 1987: 215). Loss of social orientation caused by the normlessness and unregulated socio-economic structure forms the very basis of anomie. Disorientated individuals are marginalized and trapped between the pressure of their expectations and failures of them. Thus, they turn out to be skeptical about social values. Anomie arises from individual and social 
unrest as a result of erosion of standards/values, namely 'normlessness'. It is a macro-sociological problem leading to individuals' alienation from their backgrounds and community. It is not only a psychological condition of individuals' alienation, anxiety or frustration, but also a social condition characterized by instability and deinstitutionalization.

Durkheim's concept of anomie is defined as "insufficient normative regulation of individuals' activities, with the result that individuals do not feel attached to the collectivity" (Turner and Beeghley, 2002: 343). His observations are based on the changing dynamics of industrialization and it would not be wrong to adapt it to the contemporary business system and its myths. At this point, it can be claimed that the normless American Dream is the main incentive behind the confusion and alienation of citizens and gives way to the state of anomie, in which citizens are compelled to commit illegal and immoral acts.

According to Durkheim, the greedy strivings of man and infiniteness of his dreams make the satisfaction and happiness impossible. He presents that anomie stems from the condition of diminished values that lead to alienation, meaninglessness and suicide at the end. As American Dream has also highlighted the future aspect of hope, citizens do not dare to give up their pursuit although they confront with the reality; illusion induces them to the possibility of achieving ceaselessly in the future. Americans, blind toward this reality, struggle hard for achieving the illusion; for anomic people are trapped in their futile search of material well-being. In this context, the dreamers of American dream can be labeled as 'anomic'. The dream has been minimized into material well-being and accumulation has no end.

The mutual interaction between 'aspiration' and the 'means' of achieving it is directly referred by Robert K. Merton. Merton's theory of anomie is based on the lack of balance between the goals and the means of achieving these goals. He argues: “...our primary aim is to discover how some social structures exert a definite pressure upon certain persons in the society to engage in nonconforming rather than conforming conduct" (1968: 186). He asserts that deinstitutionalization occurs when there is a detachment between cultural goals and institutional means (1968: 189). 'Cultural goals' are socially conformed expectations and aspirations, which is namely 'pursuit of property' in the context of American dream; 'institutional' means the socially verified ways of attaining these goals. Due to the excessive emphasis on financial success, the individuals' ties with the society are unbound in their quest of self-interest and they do not feel belonging to the society. He calls for a balance between the goals and means to achieve them. According to him, anomie follows the lack of regulating norms on the required means of achieving goals. His Strain Theory related to anomie reveals that when the institutionalized means fail to regulate and 
compensate these norms, alternative illegitimate/deviant elements are used.

Originating from the works of Durkheim and Merton, Steven F. Messner and Richard Rosenfeld developed the Institutional Anomie Theory (IAT). It proposes that high crime rates may be explained by socio-cultural structure of a society. They put forward that American culture heavily fosters people to pursuit monetary success. Messner refers to the 'survival of the fittest' aspect of this structure and places the dream in this context as such: "...broad cultural ethos that entails a commitment to the goal of material success, to be pursued by everyone in society, under conditions of open, individual competition" (1994: 69). He emphasizes the normlessness of American Dream by demonstrating the problematic aspect of it, in terms of not defining what 'play by rules' means. According to their theory, the rules are defined by four social elements: the economy, the polity, the family, and the educational system. The structure of economy, basis to American Dream, is defined as capitalistic economy. It is the cause of the high crime rates due to its domination over non-economic social institutions such as family, education and polity. American dream shows its negative influence with its stress on attainment of monetary success through competition in an unregulated system. The citizens suffer from anomic depressions and are led to criminality since the society whose norms are broken down and totally lost cannot provide logical alternatives. IAT suggests that crime in the U.S. is driven by extensive pressures to reach monetary profit, which is culturally verified as the sole criteria of success.

\section{Discussion}

The business world presented in David Mamet's (1947-) "American Buffalo" (1976) and "Glengarry Glen Ross" (1984) is a successful and downto-earth appliance of American business system into microcosmic settings. In this disclosure of the system, ethical conducts which are urged by the imperatives of the American Dream and its aftermaths such as anomie, alienation and further ramifications as deviance/crime are conspicuously unveiled. Mamet's characters in the plays bear contradictory dualities in terms of being both victims/sufferers and criminals/executers at the same time. In order not to suffer more, they execute the demands of business system; however, the more they execute, the more they suffer due to the infiniteness of their dream. The handicaps of this execution process including preoccupation with 'by any means necessary', 'winner takes all' and so on cause them to suffer from distress, estrangement, solicitude in their activities. They are gradually departed from the humanly values since this process cannot be possible without immoral and unethical acts.

David Mamet refers to anomie as "the sickness of the American Age" (2006: 89). In the labyrinth of American dream, Mamet's characters tragically suffer from this 'sickness' and present its symptoms as alienation, frustration, hostility, indifference and even crime. Physical, psychological 
and verbal violence of Mamet's anomic characters has grown out of the anomie, which generates a vacuum atmosphere in which the individuals have lost the proper ways of existence. Characters are the products of a culture, which constantly pumps the ideal of monetary gain and enforcing this as a sole measure of success. The characters' stress and frustration lead inevitable and undesirable results. The recurrent aphasia, aggression and obscenity in language and behaviors emanate from the exaggerated emphasis on monetary success and detachment from collectivity. Mamet himself told the director of a production of "American Buffalo"1 that "...the society hasn't offered them any context to be excellent in" (1985: 64). Mamet's rationalization can be likened to that of Merton in terms of stressing out the importance of disconnection between social goals and the institutional means to realize them. It is also true for "Glengarry Glen Ross"2; social structure puts strong emphasis on the success through money, however does not present the means.

In the real estate office in $G G R$, a competition among salesmen takes place at the end of which, top man wins a Cadillac, the second man wins a set of steak knives, the bottom two men get fired. The salesmen who are devoid of ethical guidance are forced to act in accordance with their subjective norms of consequentialism. In consequentalism, moral standards of an action are measured according to its outcomes. This highly pragmatist approach can also be attributed to the concept of 'the end justify the means', which is attributed to Machiavelli or Ovid. In the opening scene of "GGR", Shelly Levene offers to his boss, John Williamson, a certain percent from his commission as a bribe for taking best deals. Feeling the strong pressure of realizing his dream of success in a society that 'hasn't offered (him) any context', Levene's anomie is triggered and leads him to find illegal solutions of his own. At this point, crime comes into existence as a result of socioeconomic structure. However, Williamson's response to the bribery is another example of deviance in the business system. Although anomie was originally employed to reveal the connection between economic conditions and suicide rates, it is also adapted to the American business system in terms of giving way to 'white collar crime', which was first coined by criminologist Edwin Sutherland and defined as "a crime committed by a person of respectability and high social status in the course of his occupation" (1996: 102). In this sense, Williamson's tendency towards bribery can be evaluated as a white collar crime which is an outcome of anomie in the business system. It also fits to the Durkheimian conception of normality of crime. Nature of the cultural goals and the means give rise to such deviant actions. Criminality may not be justified but rationalized in this context.

The extraordinary accentuation of the dream on monetary profit is the basic motive for Williamson's admittance of bribery. For " $A B$ ", bribery is a

\footnotetext{
1 "American Buffalo" is hereafter abbreviated as "AB".

2 "Glengarry Glen Ross" is hereafter abbreviated as "GGR".
} 
natural synonym of crime. At the outset of the play, the dialogue between Don Dubrow and his gopher Bob presents their robbery plan as a metaphor of business. All of the three characters of the play are outcasts who are striving for gaining monetary profit. Yet, the established socio-economic structure of contemporary America is far away from proposing them the acceptable means. Trapped between realizing their dream and conforming themselves to admissible social acts, the characters find their own way of solution to this paradox by adopting a robbery plan. Social institutions fail to supply them with the required means and the robbery plan is accepted without its moral validity since 'the ends justify the means'. Mamet can be considered as a social dramatist with regard to his exposure of capitalistic structure of America as impelling incitement to illegal actions: "American Dream has gone bad....it was basically raping and pillage. The idea was that if you got out there, as long as there was something to exploit - whether it was Wild West, the Negroes, the Irish, the Chinese in California, the gold fields, or the timberland - one had the capacity to get rich. This capitalistic dream of wealth turns people against each other" (1992: 89). American dream's inclination toward 'raping and pillage' forms the very core of Mametian sense of anomie. Anomie as a persistent state of America is recurrently observed in his plays.

As early as the first scene in "GGR", we are informed about the characters' inclination to deviance through the bargain between Shelly Levene and his boss John Williamson. Bargain speech also reveals the paradoxical stalemate since the only way to sell is to have the best leads, yet the best leads are given to those who sell most. In this contradictory setting, Levene has no chance but to yield to frustration and soon anomie. It is his anomic situation that provokes him to burglarize his office. Merton casts the blame of employing illegal methods on the American Dream. King directly refers to such kind of conflict in Mametian sense of anomie: "...overt physical violence is always regarded as deplorable in Mamet's plays, which are sensitive to ethical issues and dramatize the conflict between individual needs and the demands of the community. It is never clear whether the individual in the community will survive this conflict" (2004: 137). For Mamet's plays, it can be observed that individual's only way to survive this conflict is to indulge in deviance or being totally alienated.

The belief of being 'special' takes its roots from the foundation myths of the country. For Mamet's characters the idea of being 'special' clashes with the material realities of the degenerated world. At this point, incapability of perceiving what is 'accurate' causes the state of anomie in which characters are led by their own frustration and bewilderment. There is a direct proportion between the expectations and the disappointment felt after failure. The greater expectations one has, the greater disappointment he/she feels. Bigsby points out the catastrophic position of Mamet's characters as such "...they are stranded in a world which generates anxiety and alarm and which offers nothing but fantasy to assuage them. They have lost control of 
their lives" (1985: 66). Their lives are directed by jungle laws, which also have no standard and open to subjective interpretation and executions.

Besides Durkheim's anomie theory, alienation theory of Karl Marx is important to highlight the characters' catastrophe. Marx wrote in The German Ideology that "...as long as a cleavage exists between the particular and the common interest....man's own deed becomes an alien power opposed to him, which enslaves him instead of being controlled by him" (1970: 53). His criticism of capitalism was not only about the economic dynamics but also about the detrimental impacts of market economy on the worker's psychological and social life in terms of alienation. Alienation is defined as an aftermath of private property in capitalism. It is seen in microcosmic and macrocosmic levels in both plays of Mamet. The characters'deviant actions stem from the alienation from themselves, from their colleagues and from their society.

By the time 'they have lost the control of their lives', they have lost the control over the conditions of employment and immediate work process, as well. At this point, since the 'alien power' has annihilated the tie between the truth and illusion, crime is normalized in the minds of the characters. Nightingale mentions about the crooks of " $A B$ " that they "...convince themselves that crime is no 'shame' and that their victims deserve to be plundered" (2004: 93). Since the bond between men and his surrounding is broken, humanly interactions and values are considered as commodity that can be 'plundered'. Tyson directly refers to the connection between commodity and American dream as such "...American dream is, inherently, a commodified dream, and it promotes commodification as a psychological stance...American dream and commodity are virtually interchangeable, for the American dream is the ideological apparatus of the commodity" (Tyson, 1994: 6). In both plays, besides virtual commodities like 'buffalo-head nickel coin' and 'deals', all social interactions are also commodified as articles of trade and commerce, and then 'plundered' for the sake of personal profit. Greed for commodity itself which over time turns out to be commodity fetishism and tendency toward commodifing the values is stemmed from the excessive stress of dream on accumulation of property. Human relations are also commodified; the characters see one another as objects of business.

In "GGR", the 'winner takes all' pattern of American dream is solidified with the competition at the end of which the top salesman will take the Cadillac and last two men will be fired. Since the only valid regulation is 'winner takes all', competitors have no chance except adapting themselves to 'the ends justify the means' rule. The main point is the 'survival of the fittest'; yet, the question of how to survive does not matter. In the first act of the play, the course of the speech reveals the key points that take Levene to the climax of the crime. First, Levene demands good deals from his boss referring to his successful sales in the past. However, his boss is in absolute indifference to his worker. His indifference triggers Levene's anomic state; 
his frustration has been reproduced recurrently by his every instance of being refused. Disagreement between Levene and Williamson is only the seeming aspect of his anger; in fact, Levene's anomie is deeply rooted in the social and economic unrest. Barranger briefly explains Levene's situation: "Increasingly desperate, one of the salesmen, Shelly Levene, breaks into the office and steals the premium address list of potential clients. Police are called to investigate the 'crime'. By contrast, the salesman's day-to-day activities as they go about deceiving their customers are regarded as good business tactics, sanctioned by the ethics of a world in which success is the ultimate achievement" (2006: 191). While Barranger reveals the very irony of the play, King evaluates Levene's theft as a "representative of responses to a greed-driven world, which fails to provide affection for those who crave it or opportunities for principled behavior to those who aspire it" (2004: 149).

In "AB", Don's resale shop is the setting where deleterious effects of social anomie can be observed. The plot is so astonishingly simple that Act I revolves around the plan of a robbery and Act II presents the failure of it. Although Don originally plans to realize the robbery with his gopher Bob, Teach, with a serial of manipulations, manages to persuade Don about disqualifying Bob. The early conversation between Don and Bob reveals that there is a real affection between them. Don, like a concerned father, warns Bob against smoking, malnutrition and coffee. Nevertheless, as soon as the common interests seem to clash, Don does not hesitate to disqualify him. The pressure of greed to possess material wealth easily intensifies his alienation toward his close friend. In the anomic atmosphere of the resale shop, traditional conduct of trade and concept of friendship lose their meanings. Nonetheless, this corruption does not spring from the deviance in their personalities. Teach clearly verbalizes that 'the country is founded on this' rule: "Teach: The freedom.... Of the Individual... To Embark on any Fucking Course that sees fit...In order to secure his honest chance to make a profit.... The country's founded on this, Don..." (Mamet, 1977: 72-73).

Teach's declaration of individual freedom in contemporary America refers to its foundation. What he perceives as 'freedom' is actually abandonment. In the contemporary America, citizens are not provided with guidance in their quest for individual dream. The Dream loses its utility as a means of a better life, but turns out to be a holy aim that enslaves its prayers. Breakdown of regulation and guidance comes with the breakdown of social consciousness and collectivity; what follows is men's illusionary perception of freedom which lacks offering salvation but fertile in generating deviance. An individual believing this misperception thinks that he has right to 'embark on any fucking course that sees fit'. For "AB", Don, Teach and Bob see fit to commit a robbery since they have to 'secure (their) honest chance to make profit'. Exaggerated emphasis on the making 'profit' normalizes the crime. That is why business is recurrently used as synonymous with robbery. In their world, main objective of business is to 'make profit' 'by any 
means necessary', how to make is out of concern. Teach mentions robbery as "tak(ing) what's ours"(77); in the same way, crime is also normalized in the minds of the salesmen in "GGR" since the nature of their work entails lying and betraying clients in order to sell worthless lands. The key points of the speech between Aaronow and Moss reveal their conceptualization of crime. Aaronow, as an 'unfavourable variation', rejects Moss' robbery plan on the ethical grounds that it is a 'crime'; however, Moss normalizes the 'crime' as a 'safe' way of getting what they want.

"Aaronow: Because, because, you know, it's a crime.

Moss: That's right. It's a crime. It is a crime. It's also very safe" (Mamet,2001a:18). Since Moss is highly alienated from the process of employment, he does not hesitate to commit in robbery; on the other hand, his alienation from his colleagues gives way to his manipulation of innocence. However, his deviance can only be judged in terms of the anomic conditions that feeds the evil in him.

Mamet himself states that American myth is the main incentive behind the character's catastrophe: “...that American myth: the idea of something out of nothing. And this also affects the spirit of the individual. It's very divisive. One feels one can only succeed at the cost of someone else" (2001b: 47). Analogous to the observations of prominent sociologists, Mamet puts forward that is the 'American myth' what deteriorates 'the spirit of the individual'. Mamet's characters are the victims of their society. That is why Bigsby puts forward that they do not live but perform: "...deracinated characters, with those who perform rather than live their lives..." (2004: 7) Mamet's characters are not completely blind to the catastrophe of their world. Towards the end of "AB", Teach shows the very anomic condition:

"Teach: The Whole Entire World. There is No Law. There is No Right and Wrong. The World is Lies. There is No Friendship. Every Fucking Thing. (Pause) Every God-forsaken Thing....

Don: Calm down, Walt.

Teach: We all live like the cavemen" (Mamet, 1977: 103).

The facts that there is no law and the world is composed of lies reflect the modern/primitive atmosphere of morality. The metaphor of cavemen suits for the modern human beings who have no laws except hunting and gathering for themselves. In both plays, modern businessmen act like 'cavemen' who only care for primitive instincts. Therefore Mamet considers that American dream was basically 'raping' and 'pillage'; “...we are finally reaching a point where there is nothing left to exploit...the dream has nowhere to go so it has to start turning to itself" (Mamet, 1988: 133). At the end of "GGR", Roma directly goes to the restaurant to find new clients, however Aaronow chooses to settling alone into a desk chair and says that "Oh, god I hate this job" (Mamet, 2001a: 66). 
As Teach in "AB" publicizes in a lawless world, the collapse of norms to identify the right and the wrong is inevitable. In his sudden manifestation of the world as a wasteland, Teach confesses that they are living like cavemen thoroughly directed by instincts. The American Dream was initially appreciated by people all around the world as a means of fulfilling their expectations and hopes. Since the dream holds connotations of 'unlimited aspirations', it would be ambiguous to list the impulses behind this quest.

However, it can be said that some people desired to enjoy religious freedom; some people imagined the new land as a chance to escape from prejudices; some people noticed the untouched opulence. As the existence of America has dramatically changed in the course of the history, the dream, its associations and its feasibility have altered likewise. In the contemporary America, the holy national dream of salvation transformed into individual salvation through material wealth. The individuals who are free to pursue their own dreams are also free to employ every means, no matter what it requires. Such a freedom in this context, independent from ethical sanctions, inescapably leads to a chaotic and suffocating atmosphere of anomie. In the anomic aura of the country, as a result of fevered alienation from themselves and their society, people remove every obstacle standing before their dream. Without considering its moral or ethical validity, every deviance is normalized, justified and even blessed for the sake of achieving ultimate monetary goals. The absence or collapse of ethics shows itself.

"AB" and "GGR" present us the imperatives and their immediate impacts on individuals and on society in accordance with the alienation and anomie theories. Deviance is the most recurrent expression of perceiving others as rivals or enemies. In the real estate office, the salesmen do not 'fight fair' since they are totally estranged to each other; they are not 'fair' to their clients since they are also estranged from the society they live in. In "AB", Don and Bob who are good friends at first, turn out to be 'strangers' to each other due to the conflict of interests. In both plays, anomie and alienation reverberate through the characters' conduct with the process of their employment, interaction with colleagues, position in the society and the perception of their own existences. Anomie as an aftermath of ruthless American business system and American dream has also its own aftermaths. It bears a powerful and threatening capacity to turn a society into a 'wreck'. Mamet depicts a wasteland of the fragmentation of universal values anomie- in the contemporary American business system in the plays.

\section{Conclusion}

"AB" and "GGR" not only deal with the pressures and handicaps of the American business system on the individual level, but also explore the very ramifications of it on the social and universal level. The American dream's resonance on the characters is tragic since they are compelled to indulge in the 'deviance' in order to actualize it. The characters are in one hand triggered with the greed of material possession, on the other hand devoid of 
any ethical guidance in their search. Therefore, conflicts between the dream's theoretical manifestation and its applicability cause a suffocating anomic setting. They are the victims of the capitalist system and the myth of the American dream. That is the normless American business system, in which the characters are driven by the impetus of their dreams. It forms the whole paradox and generates the deviance/crime. In both plays, unethical methods in the system normalize the deviance, which occurs as manipulating and misleading the customers and colleagues by lying, cheating, betraying, fighting, bribing and stealing. Moreover, the unethical conducts of the businessmen grow out in a hierarchical line from top to bottom. Since only the 'fittest' has chance to survive and being 'the fittest' requires deviance in this unfair competition, Mamet's characters are fittingly called as "capitalist victims of capitalism" (Sauer, 1996: 131).

The collapse of spiritual values and the domination of capitalist principles, which are befitting to self-interest may be considered as both the reasons and the results of anomie. Anomie and its further extensions as deviance are inevitable in a society, which 'has been fallen apart'. Mamet's characters in both plays do not know what they 'should be doing' and the social structure in general is unable to advise them what they should do. Social structure, which superfluously stresses on the embellished American Dream of material well-being, turns citizens into criminals. Roudane evaluates the relation between 'the American ethic of business' and its ethos that affects the individual as such: "This relationship, in American Buffalo as in Glengarry Glen Ross (1983), prompts debates about the individual's sense of public responsibility and his or her definitions of private liberties. Throughout his theatre, Mamet creates a dialectic which, on the one hand, recognizes the individual' right to pursue entrepreneurial interests, while, on the other hand, concedes that in an ideal world such private interests should, but do not, exist in equipoise with a sense of civic and moral duty" (2004: 58). In both plays, the collapse of 'equipoise' between personalinterests and public responsibility is inevitable since social, institutional and private interests constantly clash with each other. The choices of the characters in the problematic situations are mainly determined by the intensive individualistic instincts; that is why at the end of the play, Teach shouts 'we all live like cavemen'. Consequently, early pursuers of 'happiness' are transformed into 'cavemen' relentlessly marching for their individual needs.

\section{REFERENCES}

Barranger, M.S. (2006). Theatre: A way of seeing. California: Thomson Wadsworth.

Bigsby, C.W.E. (1985). David Mamet. London: Methuen \& Co.,

Bigsby, C.W.E (ed.) (2004). The Cambridge companion to David Mamet. Cambridge: Cambridge University Press.

Carlin, G. (1997). Brain droppings. New York: Hyperion. 
James, W. (2012). Classics of Western Philosophy. (ed. Steven M. Cahn), Indianapolis: Hackett Publishing Company Inc.

King, K. (2004). Gradations of criminality in the plays of David Mamet. The Art of Crime, (ed. Leslie Kane), New York: Routledge.

Köseman, Z. (2016). William Dean Howells' Work Ethic in The Rise of Silas Lapham. Capitalism and Commerce in Imaginative Literature, (ed. Edward W. Younkins), 175-184, Lanham: Lexington Books.

Mamet, D. (1977). American Buffalo. New York: Grove Press.

Mamet, D. - C. W. E. Bigsby (1985). David Mamet. London: Methuen \& Co.

Mamet, D. - Savran, D. (1988). In their own words: contemporary American playwrights. New York: Theatre Communications Group.

Mamet, D. (1992). (Qtd in Henry I. Schvey). Power plays: David Mamet's theatre of manipulation. David Mamet: A Case Book, (ed. Leslie Kane), New York: Garland Publishing.

Mamet, D. (1996). Speaking on stage: Interviews with contemporary American playwrights. (ed. Kolin, P.C. - Kullman, C. H.), Tuscaloosa: The University of Alabama Press.

Mamet, D. (2001a). Glengarry Glen Ross. London: Methuen Drama.

Mamet, D. - M.C. Roudane (2001b). Something out of nothing. David Mamet in conversation, (ed. Leslie Kane), Ann Arbor: The University of Michigan Press.

Mamet, D. (2006). The wicked son: Anti-Semitism, self-hatred, and the Jews. New York: Nextbook.

Marx, K. - Engels, F. (1970). The German ideology. London: Lawrence \& Wishart.

Merton, R. K. (1968). Social theory and social structure. New York: The Free Press.

Messner, S. F. - Rosenfeld, R. (1994). Crime and the American dream. Belmont, CA: Wadsworth.

Nightingale, B. (2004). Glengarry Glen Ross. The Cambridge companion to David Mamet, (ed. Christopher Bigsby), Cambridge: Cambridge University Press.

Orrù, M. (1987). Anomie: History and meanings. Boston: Allen \& Unwin.

Roudane, M. (2004). Betrayal and friendship: David Mamet's American Buffalo. The Cambridge companion to David Mamet, (ed. Christopher Bigsby), Cambridge: Cambridge University Press.

Sauer, D. K. (1996). The Marxist Child's Play of Mamet's Tough Guys and Churchill's Top Girls. David Mamet's Glengarry Glen Ross: Text and Performance, (ed. Leslie Kane), New York: Garland Publishing.

Sutherland, E. - C. J. Larson - G.R. Garret (1996). Crime, justice, and society. California: Altamira Press.

Turner, J. H. - Beeghley, L. (2002). The emergence of sociological theory. Belmont CA: Wadsworth Thomson Learning.

Tyson, L. (1994). Psychological politics of the American dream. Columbus: Ohio State University Press.

URL 1. Adams, James Truslow (1931). The epic of America. Boston: Little, Brown and Company. https://archive.org/details/in.ernet.dli.2015.262385 (Access Date: 02.05.2021) 
“İyi Yayın Üzerine Kılavuzlar ve Yayın Etiği Komitesi'nin (COPE) Davranıș Kuralları” çerçevesinde aşağıdaki beyanlara yer verilmiștir. / The following statements are included within the framework of "Guidelines on Good Publication and the Code of Conduct of the Publication Ethics Committee (COPE)":

İzinler ve Etik Kurul Belgesi/Permissions and Ethics Committee Certificate: Makale konusu ve kapsamı etik kurul onay belgesi gerektirmemektedir. / The subject and scope of the article do not require an ethics committee approval.

Destek ve Teşekkür / Support and Acknowledgment: Bu makale, Eda Zirek'in Fırat Üniversitesi Sosyal Bilimler Enstitüsü Batı Dilleri ve Edebiyatları Anabilim Dalı'nda Dr. F. Gül Koçsoy yönetiminde 2009 yılında tamamladığı “David Mamet'in 'Glengarry Glen Ross' ve 'Amerikan Buffalo'sunda Amerikan İş Ahlakı" başlıklı yüksek lisans tezinden üretilmiștir. / This article is produced from the M.A. thesis written by Eda Zirek, entitled "American Business Ethic in David Mamet's 'Glengarry Glen Ross' and 'American Buffalo' completed at Firat University, Institute of Social Sciences, Department of Western Languages and Literatures, Program of English Language and Literature, supervised by Assist.Prof.Dr. F. Gül Koçsoy in 2009, in Elazığ-Tuıkey.

Çıkar Çatışması Beyanı/Declaration of Conflicting Interests: Bu makalenin araştırması, yazarlığı veya yayınlanmasıyla ilgili olarak yazarların potansiyel bir çıkar çatışması yoktur. / There is no potential conflict of interest for the author regarding the research, authorship or publication of this article.

Katkı Oranı Beyanı/ Author Contributions: Verilerin tespiti ve sınıflandırılması ikinci yazar, verilerin incelemesi ve değerlendirilmesi her iki yazar tarafından gerçekleștirilmiștir. / Detection and classification of the data was carried out by the second author, and the analysis and evaluation of the data was carried out by the first author. 